ANNA IRENA SZYMAŃSKA

Uniwersytet Pedagogiczny, Kraków, Polska

\title{
Podejście kompozycyjne i dekompozycyjne w pomiarze wyrażonych preferencji konsumentów
}

\section{Compositional and Decompositional Approaches in Measurement of Stated Consumer Preferences}

Streszczenie: Preferencje są odzwierciedleniem gustów konsumentów, ich upodobań oraz osobowości. Poznanie preferencji w dalszej perspektywie może sprzyjać lepszemu zaspokojeniu oczekiwań konsumentów, a co za tym idzie wzmocnieniu pozycji konkurencyjnej przedsiębiorstwa na rynku i zwiększeniu w nim swoich udziałów. Jest to szczególnie istotne współcześnie, gdy przedsiębiorstwa zmuszone są funkcjonować w warunkach gwałtownie zmieniającego się (wręcz turbulentnego) otoczenia.

Badania preferencji konsumentów mogą być prowadzone zarówno w oparciu o obserwacje historyczne, jak również o dane o charakterze antycypacyjnym. Te dwa źródła informacji o preferencjach pozwalają na wyróżnienie metod analizy preferencji ujawnionych oraz metod analizy preferencji wyrażonych. Preferencje wyrażone korespondują do deklarowanych zachowań rynkowych konsumentów. W badaniach preferencji wyróżnia się trzy podejścia determinujące metodologię pomiaru preferencji. Są to: podejście kompozycyjne, podejście dekompozycyjne oraz podejście mieszane.

$\mathrm{W}$ artykule omówiono dwa zasadnicze podejścia w modelowaniu preferencji konsumentów: podejście kompozycyjne oraz dekompozycyjne. Wybór jednego z nich determinuje zarówno sposób gromadzenia danych o preferencjach, stosowane metody analizy preferencji, jak również postać modelu opisującego preferencje.

Wyniki tego typu analiz mogą zostać wykorzystane w toku dalszych badań nad produktem i podjęcia działań innowacyjnych, a w efekcie przyczynić się do wzmocnienia pozycji konkurencyjnej przedsiębiorstwa na rynku i zwiększenia w nim swoich udziałów.

\begin{abstract}
Preferences reflect tastes of consumers and their personalities. Knowledge of consumer preferences in the long term can contribute to meeting their expectations better and thus strengthening the company's competitive position in the market as well as increasing its share in it. This is especially important nowadays when companies are forced to operate in conditions of rapidly changing (or even turbulent) environment.

Research of consumer preferences may be carried out both on the basis of the historical as well as anticipative data. These two sources of information about consumer preferences allow specifying methods of revealed preferences analysis and stated preferences analysis. Stated preferences applied to declared
\end{abstract}


market behaviour of consumers. There are three approaches that determine measurement of consumer preferences: compositional approach, decompositional approach and mixed approach.

The article discusses two main approaches in modelling consumer preferences: compositional and decompositional approach. Choosing one of them determines both how to collect data about preferences, methods of analysis, as well as the form of the model describing the preferences. The results of this type of analysis can be used in the course of further research into the product and taking innovative actions, and thus contribute to strengthening the competitive position of the company on the market and increase its shares in it.

Słowa kluczowe: preferencje, metoda kompozycyjna, metoda dekompozycyjna, conjoint analysis, multidimensional analysis of preference (MDPREF)

Key words: preferences, compositional approach, decompositional approach, conjoint analysis, multidimensional analysis of preference (MDPREF)

\section{WSTĘP}

Nieodzowność stałego doskonalenia systemu zarządzania przedsiębiorstwem, wynikająca z konieczności funkcjonowania w warunkach gwałtownie zmieniającego się, turbulentnego otoczenia, wymusza na przedsiębiorcach podejmowanie różnorodnych działań sprzyjających osiągnięciu wysokiego poziomu konkurencyjności oraz silnej pozycji na rynku. Niezbędne staje się wdrażanie różnorodnych koncepcji, metod czy technik organizacji i zarządzania przedsiębiorstwem. Obok powszechnie znanych już koncepcji, pojawiają się kolejne, takie jak np. zarządzanie wiedzą, zarządzanie technologiami, czy zarządzanie innowacjami. Owa różnorodność z pewnością sprzyja lepszemu opracowaniu sposobów realizacji przyjętych strategii rozwojowych oraz zdobyciu przewagi konkurencyjnej na rynku.

Rynek przedsiębiorstwa to przede wszystkim jego klienci i z tej perspektywy coraz częściej podkreśla się ogromne znaczenie budowania właściwych relacji między przedsiębiorstwem a jego klientami. Umieszczenie klienta w centrum uwagi przedsiębiorstwa, poznanie jego potrzeb, preferencji i oczekiwań, powinno stanowić punkt wyjścia na przykład w kreowaniu innowacji. Wskazane wydaje się być więc dokładniejsze, bliższe poznanie preferencji, które są odzwierciedleniem gustów konsumentów, ich upodobań oraz osobowości. Struktura preferencji utożsamiana jest ze strukturą potrzeb. Jest ona jednym z trzech czynników (obok dochodu i cen nabywanych dóbr/usług) tworzących określony plan konsumpcji. Preferencje konsumentów objawiają się w ich aktach wyboru. Poznanie preferencji konsumentów w dalszej perspektywie może sprzyjać lepszemu zaspokojeniu ich oczekiwań, a co za tym idzie wzmocnieniu pozycji konkurencyjnej przedsiębiorstwa na rynku i zwiększeniu w nim swoich udziałów.

Preferencje konsumentów mogą być badane przy wykorzystaniu różnych metod. Wybór określonej metody badawczej ma swoje odzwierciedlenie zarówno w sposobie gromadzenia danych, wykorzystanych narzędziach pomiaru, jak również sposobie ich dalszej analizy. W niniejszym artykule skoncentrowano się przede wszystkim na preferencjach wyrażonych oraz dwóch różnych metodach ich analizy: MDPREF (Multidimensional Analysis of Preference) i conjoint analysis. Wskazano na różnice występujące między tymi metodami 
wynikające z faktu, iż należą one do dwóch różnych podejść w badaniach nad preferencjami (podejście kompozycyjne oraz podejście dekompozycyjne). Materiał empiryczny wykorzystany w analizie stanowiły fragmenty wyników marketingowych badań bezpośrednich, przeprowadzonych w 2008 roku z wykorzystaniem kwestionariusza ankiety na grupie 300 respondentów. Badania dotyczyły analizy preferencji konsumentów na rynku napojów bezalkoholowych w Polsce. Prowadzone były na terenie województwa małopolskiego, a próba badawcza dobrana została metodą doboru losowego.

\section{METODY POMIARU PREFERENCJI KONSUMENCKICH}

Badania preferencji konsumentów prowadzone są zazwyczaj z wykorzystaniem źródeł historycznych lub danych o charakterze proleptycznym. Wymienione dwa źródła informacji o preferencjach umożliwiają wyszczególnienie metod analizy preferencji ujawnionych oraz metod analizy preferencji wyrażonych (ryc. 1) ${ }^{1}$.

Analiza preferencji ujawnionych prowadzi do wskazania rzeczywistych decyzji rynkowych konsumentów. W tego typu analizach wykorzystywane są dane historyczne, np. dane statystyczne przedstawiające wybory rynkowe, które już wcześniej zostały dokonane przez klientów.

Preferencje wyrażone odnoszą się do deklarowanych rynkowych zachowań konsumentów, a informacje gromadzone są w drodze przeprowadzenia sondaży pośrednich lub bezpośrednich, których celem jest identyfikacja nabywczych intencji konsumentów w czasie prowadzenia badań. W badaniach preferencji wyróżnia się trzy podejścia determinujące metodologię ich pomiaru i są to: podejście kompozycyjne, podejście dekompozycyjne oraz podejście mieszane.

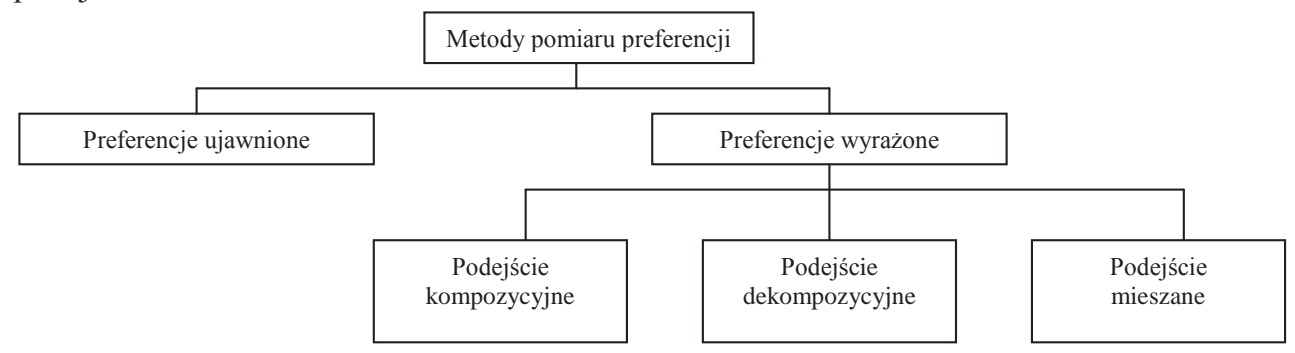

Ryc. 1. Metody pomiaru preferencji konsumentów

Źródło: Szymańska 2011,2012b; Bąk 2004: 42;Zwierna 1997: 2-3; Green, Srinivasan 1990; Kemperman 2000: 83

Ogólnie rzecz ujmując, w metodach dekompozycyjnych badane produkty porównywane są między sobą, natomiast w metodach kompozycyjnych poszczególne cechy produktów są oceniane lub porównywane niezależnie, wraz z oceną preferencji tych produktów. Przy

${ }^{1}$ Szerzej na ten temat: Bąk 2004; Szymańska 2012; Szymańska 2011; Szymańska 2007; Dziedzic, Szymańska 2005. 
czym, w podejściu kompozycyjnym użyteczność całkowita wielowymiarowego profilu dobra/usługi określana jest za pomocą ważonej sumy wskaźników i ich wag dla poszczególnych poziomów cech. Wagi mają na celu określenie „ważności” poszczególnych atrybutów dla konsumentów uczestniczących w badaniu (Bąk 2004: 43; Lilien, Kotler, Moorthy 1992: 22, 239; Green, Srinivasan 1990; Zwierna 1997: 2-4; Sagan 2004: 115; Szymańska 2011). Zarówno wskaźniki, jak i ich wagi umożliwiają również wyznaczenie ogólnej preferencji dla alternatywnych obiektów (dóbr/usług) określonych za pomocą podobnych cech.

Punktem wyjścia w badaniach preferencji prowadzonych z wykorzystaniem metod dekompozycyjnych jest natomiast ogólna preferencja konsumentów, odnosząca się do badanego obiektu wielowymiarowego. Preferencję tę poddaje się dekompozycji, w efekcie czego otrzymuje się wskaźniki cząstkowe dla poszczególnych cech badanego obiektu. Przeprowadza się oszacowanie wag poszczególnych cech badanego obiektu oraz ich poziomów, a respondenci oceniają profile badanych obiektów opisanych za pomocą określonych cech. W efekcie tych działań uzyskiwane są dane prezentujące całkowite preferencje względem poddanych ocenie profilów. Uzyskane preferencje całkowite poddawane są następnie dekompozycji i obliczane są tzw. użyteczności cząstkowe (Bąk 2004: 43; Green, Wind 1975: 107-117).

W mieszanych metodach pomiaru preferencji konsumentów wykorzystuje się zarówno elementy podejścia kompozycyjnego, jak i dekompozycyjnego, między innymi modele hybrydowe conjoint analysis oraz adaptacyjną ich wersję.

Tradycyjna analiza conjoint zapewnia duży realizm i uniwersalność wyników. Jest jednak metodą dość skomplikowaną i czasochłonną. Metody kompozycyjne są natomiast mniej skomplikowane w fazie gromadzenia danych, co ma szczególne znaczenie w sytuacji, gdy proces modelowania dotyczy wielu atrybutów i ich poziomów. Z drugiej jednak strony, tradycyjna analiza conjoint może zawierać element interakcji, której to relacji modele kompozycyjne nie są w stanie oszacować. Natomiast modele mieszane łączą w sobie szybkość i prostotę modeli kompozycyjnych oraz realizm i uniwersalność modeli tradycyjnej analizy conjoint (szerzej na ten temat: Szymańska 2007, 2011, 2012a, 2012b, 2013).

\section{ANALIZA PREFERENCJI KONSUMENTÓW Z WYKORZYSTANIEM KOMPOZYCYJNEJ METODY MDPREF}

Metoda MDPREF (Multidimensional Analysis of Preference) ${ }^{2}$ należy do grupy metod kompozycyjnych wykorzystywanych w pomiarze preferencji konsumentów. Jest to analiza czynnikowa umożliwiająca opracowanie struktury czynników kształtujących preferencje respondentów uczestniczących w badaniu oraz analizę preferowanych produktów (Dunn-Rankin, Knezek, Wallace, Zhang 2004: 164). Wyniki analizy uzyskane w efekcie zastosowania metody MDPREF przedstawiane są w postaci graficznej w formie biplotu (ryc. 2), przy czym produkty oznaczane są jako punkty, konsumenci zaś poprzez wektory wychodzące

${ }^{2}$ Carroll i Chang opracowali w 1968 roku program służący do analizy preferencji konsumentów za pomocą metody MDPREF. 
z początku układu współrzędnych. Zestawienie na jednym wykresie punktów odwzorowujących badane produkty oraz wektorów reprezentujących uczestniczących $\mathrm{w}$ badaniu respondentów, umożliwia wyznaczenie najbardziej oraz najmniej preferowanych produktów. Różne kierunki poszczególnych wektorów oznaczają natomiast zróżnicowanie preferencji konsumentów. Jest ono zazwyczaj efektem oddziaływania czynników demograficznych, ekonomiczno-społecznych, psychologicznych, marketingowych i innych. W pewnych przypadkach na biplot mogą zostać również naniesione wybrane charakterystyki konsumentów (Moser, Liang 2013; Carroll 1972: 105-155; Kuhfeld 1992: 1304-1312).

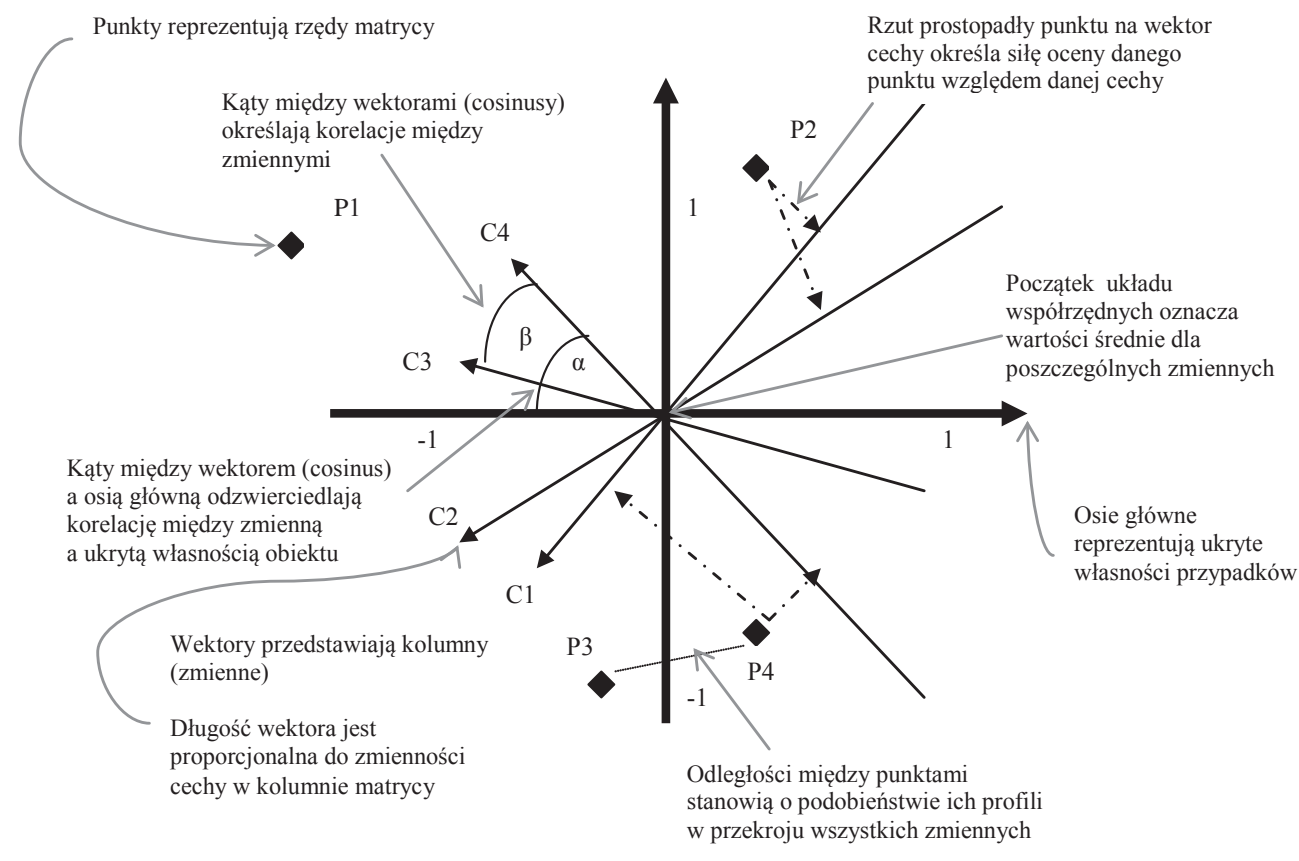

Ryc. 2. Podstawowe zasady interpretacji biplotów

Źródło: Sagan 2004; Szymańska 2011

Zebrany w 2008 roku materiał empiryczny poddano analizie z wykorzystaniem metody MDPREF. Dane, stanowiące rezultat badań ankietowych, zebrano w postaci tabeli, której wiersze reprezentowały marki produktów, a kolumny ich cechy. Tabelę tę poddano następnie dekompozycji stosując przy tym analizę korespondencji. W efekcie zastosowania owej analizy uzyskano biplot kowariancyjny prezentujący średnie wartości ocen zadowolenia klientów z wybranych cech napojów gazowanych oraz współczynniki korelacji między tymi cechami. Pozwolił on na określenie zależności zachodzących jednocześnie między porównywanymi produktami i ich cechami oraz między różnymi grupami respondentów. 
Interpretacja biplotu wskazuje, że najmniejsze odległości euklidesowe (w linii prostej) między sobą posiadają marki Fanta (FA) i Sprite (SP) oraz 7UP (7U) i Mirinda (M). Pary te charakteryzują się najbardziej podobnymi profilami reakcji w przekroju wszystkich analizowanych zmiennych. Marka 7UP jest najbliżej początku układu współrzędnych, jest więc najbardziej zbliżona do wartości średnich poszczególnych zmiennych.

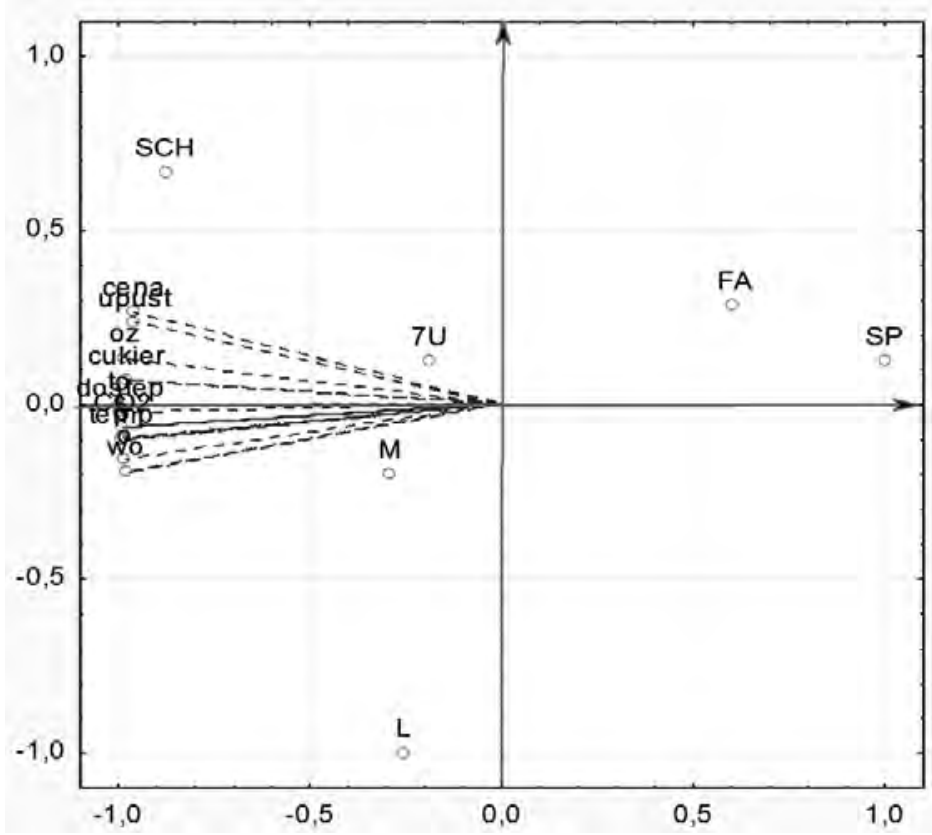

FA - Fanta, SP - Sprite, L - Lift, M - Mirinda, 7U - 7UP, SCH - Schweppes, cena - cena produktu, s - smak, dostęp - dostępność produktu, CO2 - zawartość CO2, o - orzeźwienie, p - gaszenie pragnienia, to - typ opakowania, kofeina - zawartość kofeiny, wo - wielkość opakowania, cukier - zawartość cukru w napoju, temp - temperatura, upust - upusty, oz - opakowanie zbiorcze

Ryc. 3. Biplot kowariancyjny prezentujący preferencje konsumentów odnośnie wybranych marek napojów gazowanych oraz ich cech

Źródło: opracowanie własne w oparciu o program STATISTICA 8

Cechy produktów posiadające najdłuższe wektory to smak, opakowanie zbiorcze oraz upust (ryc. 3). Wynika stąd, iż cechy te mają największą moc dyskryminacyjną, tj. zdolność różnicowania badanych marek napojów gazowanych. Nieco mniejszą rolę odgrywają cena, dostęp, zawartość CO2 w napoju, gaszenie pragnienia, orzeźwienie, wielkość opakowania. Najkrótsze wektory, a co za tym idzie najmniejszą moc dyskryminacyjną, posiadają typ opakowania oraz zawartość cukru w produkcie. Należy zwrócić tu uwagę na fakt, iż różnice w długości wszystkich analizowanych wektorów są niewielkie. 


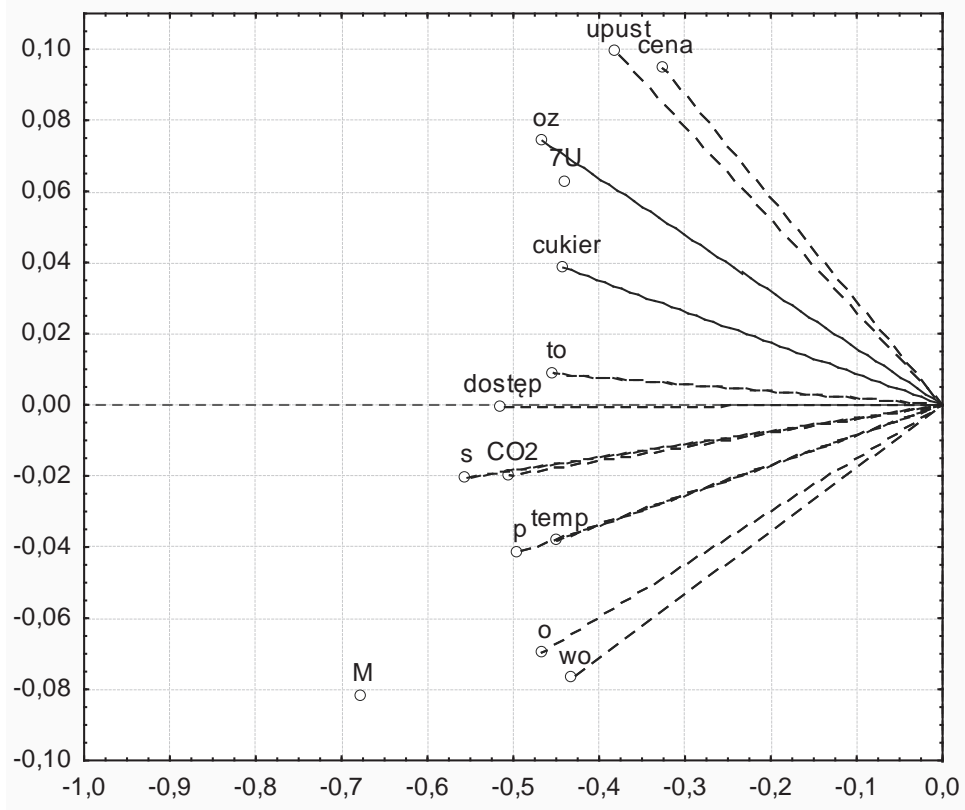

Ryc. 4. Fragment biplotu kowariancyjnego z rys. 3. ilustrujący wektory cech napojów gazowanych

Źródło: opracowanie własne w oparciu o program STATISTICA 8

Kąty między wektorami (ryc. 4) wskazują na skorelowanie zmiennych. Wszystkie są zorientowane w tym samym kierunku, względem jednego bieguna osi głównej, co świadczy o dodatnim skorelowaniu wszystkich zmiennych. Kąty między wszystkimi zmiennymi są niewielkie, co świadczy o silnym skorelowaniu tych zmiennych. Najsilniej skorelowane pary zmiennych, w przypadku których kąty są najmniejsze, to upust i cena, typ opakowania i dostęp, smak i zawartość CO2 w napoju, pragnienie i temperatura napoju, orzeźwienie i wielkość opakowania. Między wektorami ceny i wielkości opakowania brak jest jakiejkolwiek korelacji. Wektory te skierowane są do siebie pod kątem $90^{\circ}$.

Rzuty prostopadłe punktów reprezentujących wiersze na wektory zmiennych wskazują na siłę wartości ocen elementów w wierszach w przekroju każdej zmiennej. Z punktu widzenia zmiennej dostęp najwyżej oceniona została marka Sprite (ryc. 5), a nieco niżej Fanta. Wartość poniżej średniej uzyskały marki $7 U P$, Lift i Mirinda. Natomiast najniższą ocenę uzyskała marka Schweppes.

Podobnie jak w przypadku w/w zmiennej również z punktu widzenia zmiennych $d o-$ stęp i orzeźwienie poszczególne marki uzyskały podobne ilości punktów. Najwyższą ocenę uzyskał punkt reprezentujący markę Sprite. Nieco niższą ocenę ma Fanta. Wartość poniżej średniej uzyskały marki 7UP, Lift i Mirinda. Najniższą ocenę uzyskała marka Schweppes.

Najwyższą ocenę z punktu widzenia zmiennej cena uzyskały marki Sprite, Lift i Fanta. Wartość na poziomie średniej uzyskały marki Mirinda i 7UP. Najniżej pod względem tej zmiennej oceniona została marka Schweppes. 


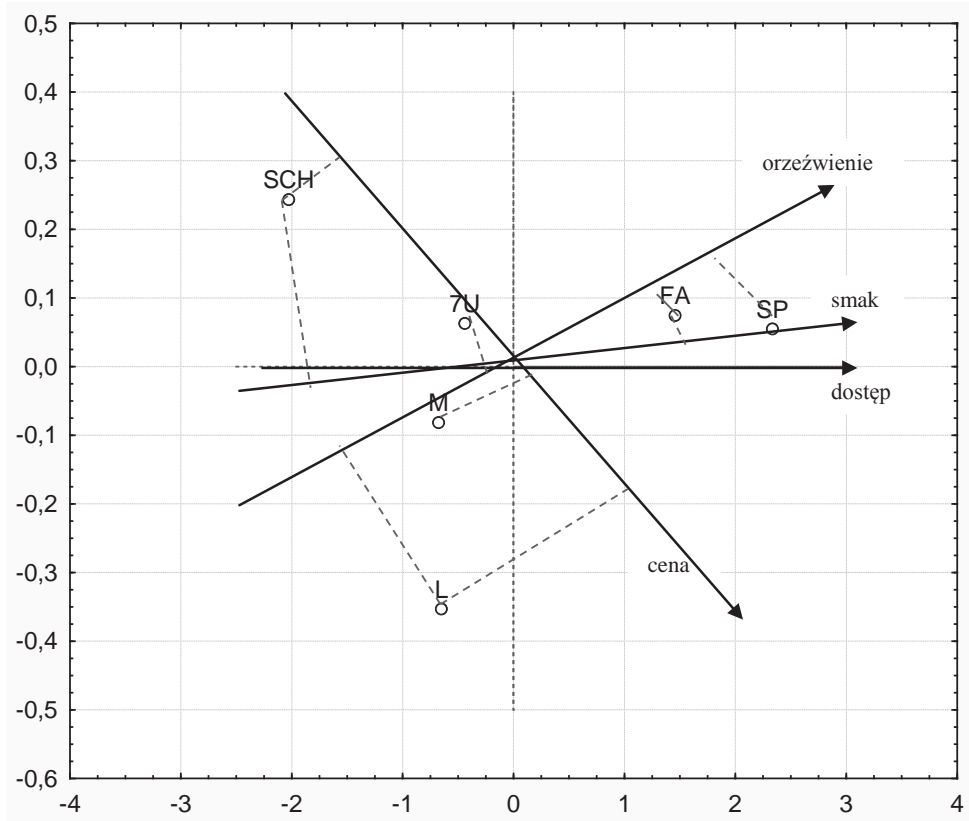

FA - Fanta, SP - Sprite, L - Lift, M - Mirinda, 7U - 7UP, SCH - Schweppes

Ryc. 5. Biplot kowariancyjny prezentujący zależności między wybranymi markami napojów gazowanych a ich cechami

Źródło: opracowanie własne w oparciu o program STATISTICA 8

\section{ANALIZA PREFERENCJI KONSUMENTÓW Z WYKORZYSTANIEM DEKOMPOZYCYJNEJ METODY CONJOINT ANALYSIS}

Metoda conjoint analysis określana jest w polskiej literaturze naukowej jako analiza kombinacji atrybutów (Ratajczak 1999: 67), analiza koincydencji (Altkorn, Kramer i in. 1998: 17), pomiar łącznego oddziaływania zmiennych (Walesiak 1996: 89), analiza kojarzenia cech (Mynarski 1996a, 1996b), pomiar wieloczynnikowy (Kaczmarczyk 2003: 172), analiza skojarzeń (Kotler 1994: 136) lub addytywny pomiar łączny (Coombs, Dawes, Tversky 1977: 50). Conjoint analysis to zespół numerycznych metod wykorzystywanych w analizie preferencji konsumentów. Metody te wynikają z założeń teorii tzw. addytywnego pomiaru łącznego (conjoint measurement) (Bąk 2003: 214; Bąk 2004: 28). Model conjoint measurement reprezentuje łączny wpływ zmiennych niezależnych na porządkową zmienną zależną w sensie matematycznym (model nie zawiera składnika losowego). Model conjoint analysis natomiast reprezentuje łączny wpływ zmiennych objaśniających na zmienną objaśnianą w sensie statystycznym (model zawiera składnik losowy) (Bąk 2004: 52; Kuhfeld 2003). Metodę conjoint analysis wykorzystuje się w pomiarze preferencji konsumentów względem 
kilku powiązanych ze sobą cech badanego produktu. Zastosowanie owej metody pozwala na dokonanie symulacji wyboru nabywców w przypadku wprowadzenia nowego lub tylko zmodyfikowanego produktu. Pozwala na dokonanie oceny poziomu parametru technicznego produktu lub poziomu ceny, który jest zadowalający dla konsumenta (Kłeczek, Kowal, Woźniczka 1997: 118).

Istnieją dwa rodzaje modeli wykorzystywanych w precyzowaniu zależności użyteczności całkowitej od użyteczności cząstkowych. Jest to model addytywny, nazywany również modelem efektów głównych, a także model efektów głównych i współdziałania uwzględniający wzajemne oddziaływanie pomiędzy badanymi zmiennymi. Wybór modelu decyduje o sposobie wzajemnego powiązania zmiennych z perspektywy respondenta dokonującego oceny profilu produktu opisanego za pomocą wspomnianych zmiennych.

Dane statystyczne niezbędne w badaniach z wykorzystaniem metody conjoint analysis pozyskiwane są zazwyczaj w efekcie prowadzonych badań ankietowych. Natomiast metody wykorzystywane do przedstawienia danych to między innymi metoda pełnych profili wyboru (full-profile approach), metoda prezentacji dwóch atrybutów jednocześnie, nazywana również metodą korzystającą z macierzy kompromisów (two-attributes-at-a-time approach lub trade-off matrix approach), metoda porównywania profili parami (pairwise comparison method), - metoda wyboru spośród zbiorów profili (the experimental choice approach), metoda oceny poziomów i atrybutów (self-explicated data approach) (szerzej na ten temat w: Walesiak 2001: 41-44; Bąk 2004: 29-31; Dziedzic, Szymańska 2005; Szymańska 2011).

Zastosowanie metody conjoint analysis pozwala na określenie wartości użyteczności cząstkowych, które to umożliwiają między innymi zdefiniowanie produktu o najkorzystniejszych cechach, zbadanie relatywnej ważności każdej zmiennej w sytuacji dokonywania przez nabywcę wyboru określonego produktu, czy też określenie udziału w rynku wybranych produktów (Mynarski 1999: 85).

Materiał badawczy pozyskany w efekcie przeprowadzenia w 2008 roku bezpośrednich badań marketingowych posłużył do przedstawienia procedury wykorzystania conjoint analysis w badaniu preferencji konsumentów. W badaniu zastosowano metodę korzystającą z macierzy kompromisów, nazywaną również metodą prezentacji dwóch atrybutów jednocześnie (trade-off matrix approach lub two-attributes-at-a-time approach). Zadaniem respondentów uczestniczących w badaniu i deklarujących spożywanie napojów gazowanych było porównanie motywów zakupu oraz dwóch grup cech zestawionych parami w formie macierzy poprzez dokonanie rankingu od najbardziej do najmniej preferowanych.

Konsumenci deklarujący spożywanie napojów gazowanych mieli za zadanie porównanie trzech grup cech zestawionych parami. Pierwszą grupę zmiennych stanowiły motywy zakupu, takie jak: zaspokojenie pragnienia, zabawa, smak owocowy, moda, dbanie o linię. Druga grupa zmiennych obejmowała smak napojów: pomarańczowy, cytrynowy, oranżada, brzoskwiniowo-jabłkowy i jabłkowy. W ramach trzeciej grupy zmiennych, którą była pojemność opakowania, znajdowały się pojemności 0,21, 0,51, 1,01 i 2,01. 


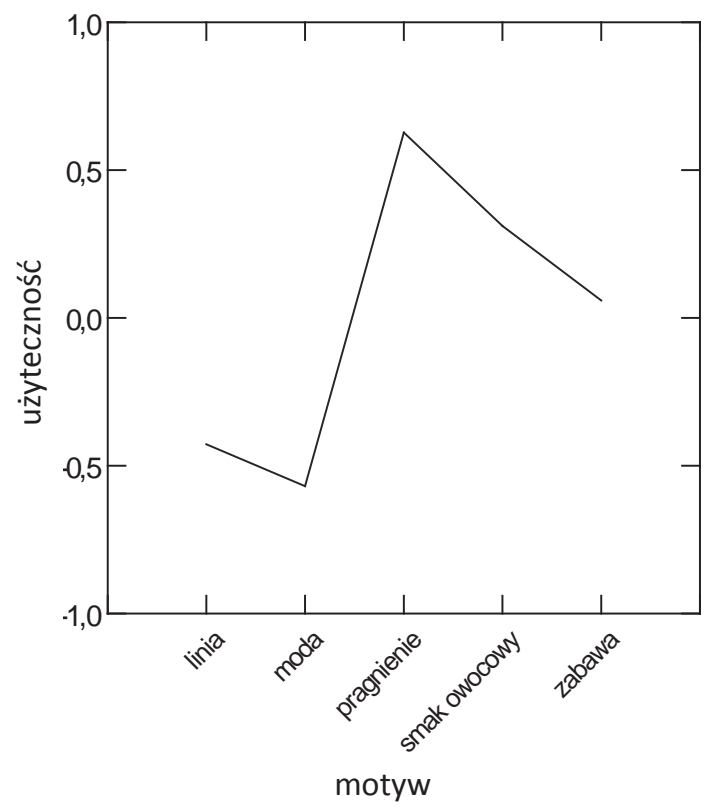

Ryc. 6. Motywy decydujące o wyborze określonych marek napojów gazowanych

Źródło: opracowanie własne w oparciu o program SYSTAT 12

Konsumenci spożywający napoje gazowane, przy ich wyborze kierowali się przede wszystkim pragnieniem (ryc. 6). Wartość użyteczności dla tej zmiennej wynosiła 0,627. Drugim, niewiele mniej istotnym powodem zakupu napojów gazowanych był smak owocowy $(0,311)$. Trzecim w kolejności motywem była zabawa $(0,059)$. Motywami o najmniejszej sile oddziaływania na preferencje konsumentów były dbanie o linię (-0427) oraz moda $(-0,569)$.

Smaki najbardziej preferowane przez ankietowanych w przypadku zakupu napojów gazowanych to smak pomarańczowy o wartości użyteczności 0,660 oraz cytrynowy - wartość użyteczności 0,364 (ryc. 7). Natomiast zdecydowanie najmniejszą siłą wartości użyteczności charakteryzowały się zdaniem respondentów napoje o smaku jabłkowym $(-0,217)$, brzoskwiniowo-jabłkowym $(-0,231)$ i o smaku oranżady $(-0,575)$.

Pojemności opakowań napojów gazowanych najbardziej preferowane przez respondentów to 1,01 o wartości użyteczności 0,544 oraz 0,51 - wartość użyteczności 0,510 (ryc. 8). Pojemnościami znacznie mniej popularnymi okazały się $0,331(-0,145)$ oraz $2,01(-0,381)$. W przypadku napojów gazowanych pojemnością najmniej preferowaną przez ankietowanych była $0,21(-0,528)$.

Podsumowując analizę z uwzględnieniem wszystkich trzech grup zmiennych można wnioskować, że najbardziej preferowanym przez ankietowanych profilem napoju gazowanego był napój o smaku pomarańczowym w butelce o pojemności 1,01 lub 0,51 kupowany ze względu na pragnienie. Natomiast najmniej popularnym profilem był napój o smaku oranżady w opakowaniu 0,21 lub 2,01 kupowany ze względu na obowiązującą modę. 


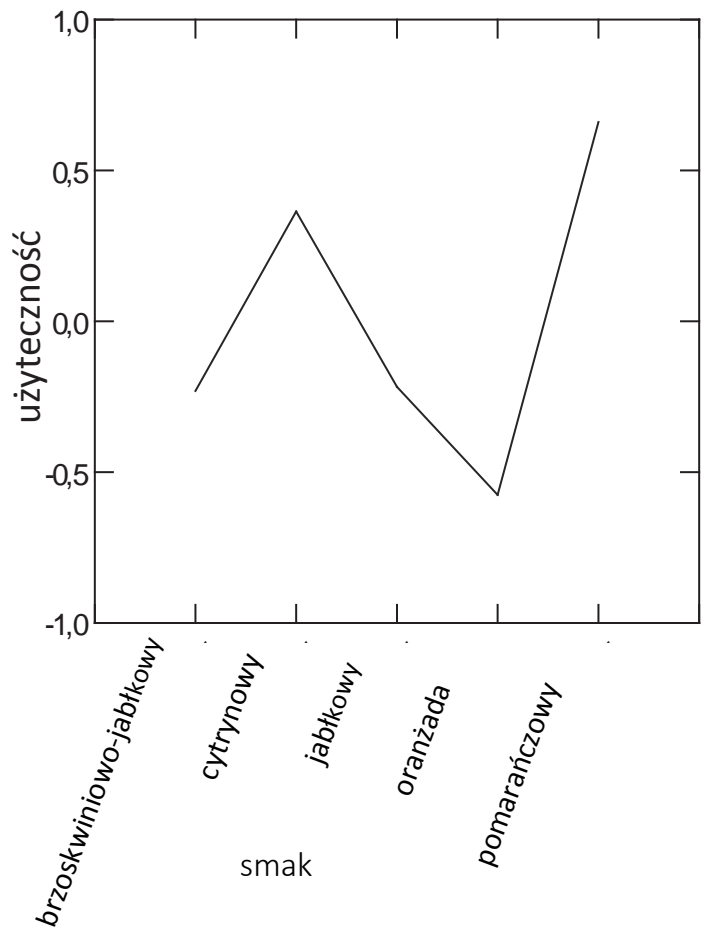

Ryc. 7. Smak jako zmienna decydująca o wyborze określonych marek napojów gazowanych Źródło: opracowanie własne w oparciu o program SYSTAT 12

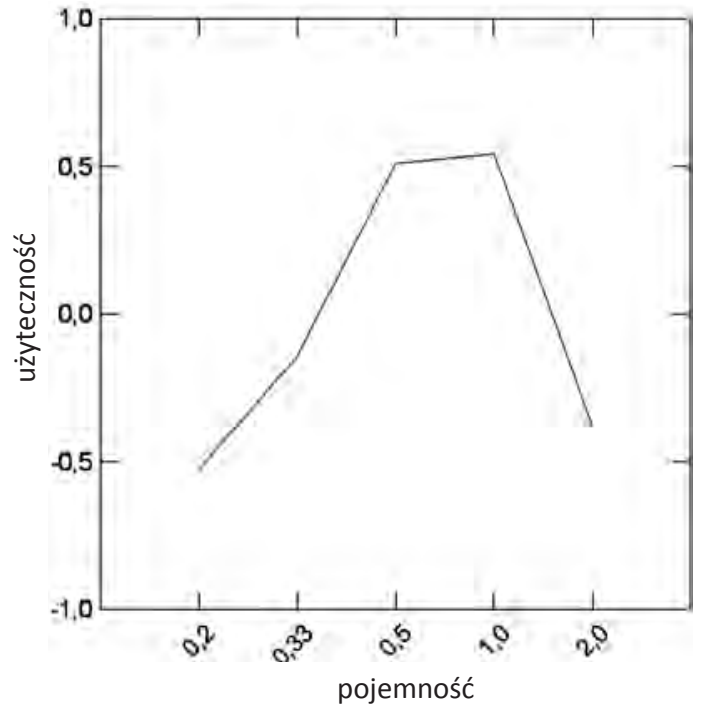

Ryc. 8. Pojemność jako zmienna decydująca o wyborze określonych marek napojów gazowanych Źródło: opracowanie własne w oparciu o program SYSTAT 12 


\section{ZAKOŃCZENIE}

Preferencje wyrażone konsumentów mogą być badane między innymi przy wykorzystaniu metod kompozycyjnych oraz dekompozycyjnych. Wybór określonej grupy metod determinuje zarówno sposób gromadzenia danych o preferencjach, stosowane metody analizy preferencji, jak również postać modelu opisującego preferencje. Przystępując do procesu badawczego należy być świadomym rezultatów, jakie przyniesie zastosowanie określonej metody badawczej.

Rezultatem zastosowania metod kompozycyjnych, których przykładem jest metoda MDPREF (Multidimensional Analysis of Preference), są jednowymiarowe, niezróżnicowane cechy opisujące badane obiekty, zaś całkowita użyteczność badanego obiektu wieloatrybutowego jest wyznaczana w postaci ważonej sumy wartości postrzeganych przez respondenta subiektywnie. Metody kompozycyjne bazują na subiektywnych ocenach respondenta.

Stosując w badaniach metodę MDPREF uzyskujemy biplot kowariancyjny, na którym produkty oznaczane są jako punkty, a konsumenci jako wektory wychodzące z początku układu współrzędnych. Zestawienie na jednym wykresie zarówno punktów jak i wektorów pozwala na wyznaczenie najbardziej oraz najmniej preferowanych produktów. Różne kierunki poszczególnych wektorów oznaczają natomiast zróżnicowanie preferencji konsumentów.

Natomiast w przypadku metod dekompozycyjnych, do których należy conjoint analysis, podstawą jest reakcja na opis badanego obiektu. W metodach tych dokonuje się estymacji użyteczności cząstkowych dla poszczególnych atrybutów (cech produktów), stosując odpowiedni model w taki sposób, aby szacowanie było maksymalnie zbieżne z ogólną preferencją respondenta. Rezultatem zastosowania w badaniach conjoint analysis jest uzyskanie profilu najbardziej oraz najmniej preferowanego produktu lub usługi.

Wyniki tego typu analiz mogą zostać wykorzystane w toku dalszych badań nad produktem. Pozyskana wiedza może stanowić przyczynek do podjęcia przez przedsiębiorstwo działań innowacyjnych, stanowiących odpowiedź na zidentyfikowane preferencje i oczekiwania konsumentów. W dalszej perspektywie może to skutkować udoskonaleniem istniejących już na rynku produktów lub też wprowadzeniem nowych, pełniej odpowiadających gustom i oczekiwaniom potencjalnych konsumentów. Działania te z pewnością wpłyną na wzmocnienie pozycji konkurencyjnej przedsiębiorstwa na rynku i zwiększenie w nim swoich udziałów.

\section{Literatura / References}

Altkorn, J., Kramer, T. (red.) (1998). Leksykon marketingu. Warszawa: PWE.

Bąk, A. (2003). Algorytmy conjoint analysis w pakiecie AS/STAT, TAKSONOMIA 10, Klasyfikacja i analiza danych - teoria i zastosowania. Prace Naukowe AE we Wroctawiu, 988, 214.

Bąk, A. (2004). Dekompozycyjne metody pomiaru preferencji w badaniach marketingowych. Wrocław: Wydawnictwo AE we Wrocławiu. 
Carroll, J.D. (1972). Individual differences and multidimensional saling. In: R.N. Shephard, A.K. Romney, S.B. Nerlove (eds.), Multidimensional Scaling: Theory and Applications in the Behavioral Sciences, Vol. 1., Seminar Press, NY, 105-155.

Coombs, C.H., Dave, R.M., Tversky, A. (1977). Wprowadzenie do psychologii matematycznej. Warszawa: PWN.

Dunn-Rankin, P., Knezek, G.A., Wallace S., Zhang S. (2004). Scaling methods. Routledge: Taylor and Francis Group.

Dziedzic, D., Szymańska, A.I. (2005). Conjoint analysis jako metoda analizy preferencji konsumentów. Zeszyty Naukowe AE w Krakowie, 680.

Green, P.E., Srinivasan, V. (1990). Conjoint Analysis in Marketing: New Developments with Implications for Research and Practice. Journal of Marketing, 54, 3-19.

Green, P.E., Wind Y. (1975). New Way to Measure Consumers' Judgments. Harvard Business Review, 53, 107-117.

Kaczmarczyk, S. (2003). Badania marketingowe. Metody i techniki. Warszawa: PWE.

Kłeczek, R., Kowal W., Woźniczka, J. (1997). Strategiczne planowanie marketingowe. Warszawa: PWE.

Kotler, Ph. (1994). Marketing. Analiza planowania, wdrażanie i kontrola. Warszawa: Gebethner i S-ka.

Kuhfeld, W.F. (1992). Marketing research: uncovering competitive advantages, Proceeding of the SAS Users Group International Conference 17.

Kuhfeld, W.F. (2003). Marketing Research Methods In SAS. Experimental Design, Choince, Conjoint, and Graphical Techniques. Cary SAS Institute. Pozyskano z: http://support.sas.com/techsup/technote/ts689.pdf.

Lilien, G.L., Kotler, P., Moorthy, S.K. (1992). Marketing models. Englewood Ciliffs: PrinticeHall.

Moser, E.B., Liang, X. Bootstrapping a Multidimensional Preference Analysis, Department of Experimental Statistics, Louisiana State University Agricultural Center, Baton Rouge, LA. Pozyskano z: http://analytics.ncsu.edu/sesug/2001/P-407.pdf (data odczytu: 02.08.2013).

Mynarski, S. (1996a). Metody badań rynkowych i marketingowych w układzie hierarchicznym. W: Metody badań marketingowych. Kraków: Wydawnictwo AE.

Mynarski, S. (1996b). Metody ilościowe. Marketing w Praktyce, 5, 9-15.

Mynarski, S. (1999). Badania rynkowe w przedsiębiorstwie. Kraków: Wydawnictwo AE.

Ratajczak, P. (1999). Stownik marketingu i reklamy angielsko-polski i polsko-angielski. Zielona Góra: Wydawnictwo KANION.

Sagan, A. (2004). Badania marketingowe. Podstawowe kierunki. Kraków: PWE.

Sagan, A. (2004). Jeden obraz ukazuje więcej niż 10 liczb, czyli jak budować mapy zadowolenia klienta z zastosowaniem programu Statistica, StatSoft. Pozyskano z: http://www.statsoft.pl/czytelnia/ marketing/04obraz.pdf (data odczytu: 02.08.2013).

Szymańska, A.I. (2007). Metodyczne problemy badań preferencji konsumenckich. Zeszyty Naukowe AE w Krakowie, 739.

Szymańska, A.I. (2011). Badania preferencji konsumentów z wykorzystaniem kompozycyjnej metody badań MDPREF. Marketing i Rynek, PWE, 10/2011, 23-30.

Szymańska, A.I. (2012a). Preferencje konsumenckie i ich determinanty. Zeszyty Naukowe WSEI Kraków, 8, 67-86.

Szymańska, A.I. (2012b). Zastosowanie dekompozycyjnej metody Conjoint analysis w badaniach preferencji konsumenckich na przykładzie napojów typu cola. Matematyka i informatyka na usługach 
ekonomii. Zeszyty Naukowe Uniwersytetu Ekonomicznego w Poznaniu, Katedra Ekonometrii, 242, 218-229.

Szymańska, A.I. (2013). User-driven innowation (UDI) - nowe podejście do innowacji a preferencje konsumentów. W: R. Pukała (red.), Zarządzanie podmiotami gospodarczymi i instytucjami. Wybrane zagadnienia. Jarosław: Wydawnictwo Państwowej Wyższej Szkoły TechnicznoEkonomicznej w Jarosławiu, 9-31.

Walesiak, M. (1996). Metody analizy danych marketingowych. Warszawa: PWN.

Walesiak, M. (2001). Gromadzenie danych w procedurze conjoint analysis. Przeglad Statystyczny, 48, $41-44$.

Zwierna, K. (1997). Discrete Choice Experiments In Marketing. Heidelberg-New York: Physica-Verlag.

Anna Irena Szymańska, dr, Uniwersytet Pedagogiczny w Krakowie, Instytut Geografii, Zakład Przedsiębiorczości i Gospodarki Przestrzennej.

Absolwentka studiów z zakresu zarządzania i marketingu Uniwersytetu Ekonomicznego w Krakowie, doktor nauk ekonomicznych w zakresie nauk o zarządzaniu (Katedra Analizy Rynku i Badań Rynkowych - Uniwersytet Ekonomiczny w Krakowie). Adiunkt w Zakładzie Przedsiębiorczości i Gospodarki Przestrzennej Uniwersytetu Pedagogicznego w Krakowie. Zainteresowania badawcze autorki oscylują wokół problematyki potrzeb, preferencji i zachowań rynkowych konsumentów, jak również zagadnień z obszaru przedsiębiorczości i innowacyjności przedsiębiorstw, ze szczególnym uwzględnieniem sektora MŚP.

Anna Irena Szymańska, Ph.D., Pedagogical University of Cracow, Institute of Geography, Department of Entrepreneurship and Spatial Management.

Graduated from University of Economics in Cracow, MA degree in Management and Marketing, $\mathrm{PhD}$ degree in Economic Sciences in the field of Management Sciences (Chair of Market Analysis and Marketing Research - University of Economics in Cracow). Senior Lecturer in the Department of Entrepreneurship and Spatial Management at Pedagogical University of Cracow. Her research interests are related to the issue of consumer needs, preferences and market behaviour, as well as issues of entrepreneurship and innovation with particular emphasis on the SME sector.

adres/address: Uniwersytet Pedagogiczny w Krakowie Instytut Geografii, Zakład Przedsiębiorczości i Gospodarki Przestrzennej ul. Podchorążych 2, 30-084 Kraków, Polska e-mail: aszym@up.krakow.pl 